\title{
POLYCLONAL ANTI-INTIMIN ANTIBODY: IMMUNOLOGICAL CHARACTERIZATION AND ITS USE IN EPEC AND EHEC DIAGNOSIS
}

\author{
Paula Célia Mariko Koga ${ }^{1,2}$; Caroline Anunciação Menezes ${ }^{1,2}$; Flávia Afonso Lima ${ }^{1}$; Júlia Mitico Nara ${ }^{1}$; \\ Caroline Arantes Magalhães ${ }^{1}$; Aurora Marques Cianciarullo ${ }^{3}$; Jorge Mario da Costa Ferreira-Júnior; \\ Luiz Rachid Trabulsi ${ }^{1}$; Meire Roberta Bresciani Mendes-Ledesma ${ }^{1}$; Roxane Maria Fontes Piazza ${ }^{1 *}$
}

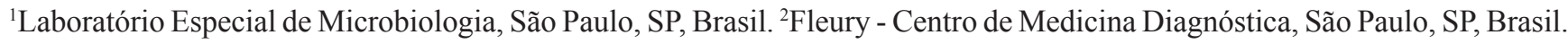
${ }^{3}$ Laboratório de Genética, São Paulo, SP, Brasil. ${ }^{4}$ Laboratório de Imunoquímica, Instituto Butantan, São Paulo, SP, Brasil.

This paper corresponds to an "extended abstract" selected for oral presentation in the $22^{\text {nd }}$ Brazilian Congress of Microbiology, held in Florianópolis, SC, Brazil, in November 17-20, 2003

\begin{abstract}
Intimins are outer membrane proteins expressed by enteric bacterial pathogens capable of inducing intestinal attachment-and-effacement lesion (A/E). Through immunoblotting, immunofluorescence, flow citometry and immunogold we observed that the obtained polyclonal antibody against conserved intimin region recognizes the different intimin subtypes and suggests that it can be used as a tool for EPEC and EHEC detection. Besides, immuno-dot assay seems to be a possible alternative as a capture method.
\end{abstract}

Key words: intimin, phenotypical analysis, polyclonal antibody, EPEC, EHEC.

\section{INTRODUCTION}

$\mathrm{A} / \mathrm{E}$ lesion is induced either by EHEC and EPEC, enterohemorrhagic Escherichia coli (EHEC), the causative agent of bloody and nobloody diarrhea as well as hemolytic uremic syndrome in humans, is prevalent in developed countries. On the other hand, enteropathogenic E. coli (EPEC) is a major cause of acute and persistent infantile diarrhea in developing parts of the world (2). EPEC and EHEC colonize intestinal mucosa by intimate attachment of bacteria to the enterocytes, which is followed by aggregation of the cytoskeleton actin and effacement of microvillus, in which intimin is an involved protein. Until now more than 10 different intimin subtypes have been described, these subtypes are defined by variable region $(a, b$, $\mathrm{g}, \mathrm{d}, \mathrm{e}, \mathrm{h}, \mathrm{i}, \mathrm{k}, \mathrm{x})(1,3,4)$. The conserved region of intimin molecule is constituted of 388-667 amino acid sequence ( $\operatorname{Int}_{388-667}$ ). Thus the aim of this study was the generation a polyclonal intimin antiserum against the conserved region and a phenotypical analysis of isolates from EPEC and EHEC using the IgG-enriched fraction of this antibody and the development of capture method for attaching and effacing E. coli detection.

\section{MATERIALS AND METHODS}

Recombinant His-Int ${ }_{(388-667)}$ expression and purification Intimin (Int 388-667 ) was obtained from recombinant bacterial strains previously cloned into pET (Novagen) system. The expression and purification were done as manufacturer's recommendations.

\section{Intimin polyclonal antiserum}

Rabbits were immunized subcutaneously with $200 \mu \mathrm{g}$ of intimin in complete Freund's adjuvant. The animals were given booster injection three times using the same protein concentration in incomplete Freund's adjuvant at intervals of 10 days. The IgG-enriched fractions were obtained from rabbit antiserum after being submitted to caprylic acid and ammonium sulfate precipitation.

*Corresponding author. Mailing address: Laboratório Especial de Microbiologia, Instituto Butantan, Av. Vital Brazil, 1500. 05503-900, São Paulo, SP, Brasil. Tel.: (+5511) 3726-7222 ext. 2075. E-mail: roxane@butantan.gov.br 


\section{Bacterial strains}

Different intimin subtype expressing $E$. coli strains: O127:H6 (E2348/69) ( $\alpha), \mathrm{O} 142: \mathrm{H} 34(\alpha), \mathrm{O} 119: \mathrm{H} 6(\beta), \mathrm{O} 128: \mathrm{H} 2(\beta), \mathrm{O} 55: \mathrm{H} 7$ $(\gamma), \mathrm{O} 157: \mathrm{H} 7(\gamma), \mathrm{O} 86: \mathrm{H} 34(\delta)$ e O103:H2 ( $(\varepsilon)$ were used. As negative control strain we used $E$. coli $\mathrm{K} 12$. All bacterial strains were grown in $\mathrm{LB}$ broth at $37^{\circ} \mathrm{C}$ for $18 \mathrm{~h}$ under constant shaking $(180 \mathrm{rpm})$ at $1 \mathrm{OD}=660 \mathrm{~nm}$.

\section{Immuno-dot assay}

Bacterial growth was boiled at $100^{\circ} \mathrm{C}$ for $5 \mathrm{~min}$ and diluted 1:100 in $0.05 \mathrm{M} \mathrm{pH} 9.6$ carbonate-bicarbonate buffer. Different volumes of bacterial suspension were applied on nitrocellulose membrane by Slot Blot Filtration Manifolds, Pharmacia ${ }^{\circledR}$ system. Reaction was done as followed: $4 \mu \mathrm{g} / \mathrm{mL}$ of IgG-enriched fraction of anti-intimin antibody and peroxidase labeled goat anti-rabbit serum (1:10000). This reaction were developed with 4-chloro- $\alpha$-naphtol (3 mg/mL) plus $\mathrm{H}_{2} \mathrm{O}_{2}$.

\section{RESULTS}

The immunochemical characterization of isolates from EPEC and EHEC using the generated polyclonal antibody against conserved intimin region through immunoblotting, immunofluorescence, flow citometry and immunogold demonstrated that the expression of intimin is recognized for the antibody in the several intimin expressing E. coli serotypes, these results are represented in Fig. 1 by immunofluorescence assay using anti-rabbit conjugated to fluorescein (FITC) showing different patterns.

In Fig. 2 we can see immuno-dot standardization for capture assay, in which we used to detect intimin-expressing strains. Bacterial growth (1DO) was centrifuged for 5 min in 5000x g, supernatants were discarded and remaining pellet was ressuspended in $100 \mu \mathrm{L} 0.5 \mathrm{M} \mathrm{pH} 6.8$ Tris/ $\mathrm{HCl}$ buffer and boiled at $100^{\circ} \mathrm{C}$ for $5 \mathrm{~min}$, followed by a $1: 100$ dilution in $0.05 \mathrm{M} \mathrm{pH} 9.6$ carbonate/bicarbonate buffer. Between different tested volumes $200 \mu \mathrm{L}$ was defined as ideal amount of protein and reaction was done using $4 \mu \mathrm{g} / \mathrm{mL}$ of IgG-enriched fraction of anti-intimin antibody and peroxidase labeled goat anti-rabbit serum (1:10000) as ideal concentration of first and second antibodies, respectively.

\section{DISCUSSION}

Although the excellent immune response obtained in each immunized rabbit with conserved intimin ( $\operatorname{Int}_{388-667}$ ) the antibody reactivity or its IgG-enriched fraction showed some inespecificity with other $E$. coli protein when tested by immunoblotting assay, which is solved by sera adsorption with $E$. coli $\mathrm{K} 12$. Through immunoblotting we could observe the reactivity of IgG-enriched fraction of anti-intimin serum with different bacterial serotypes that expresses intimin. This reactivity was confirmed by
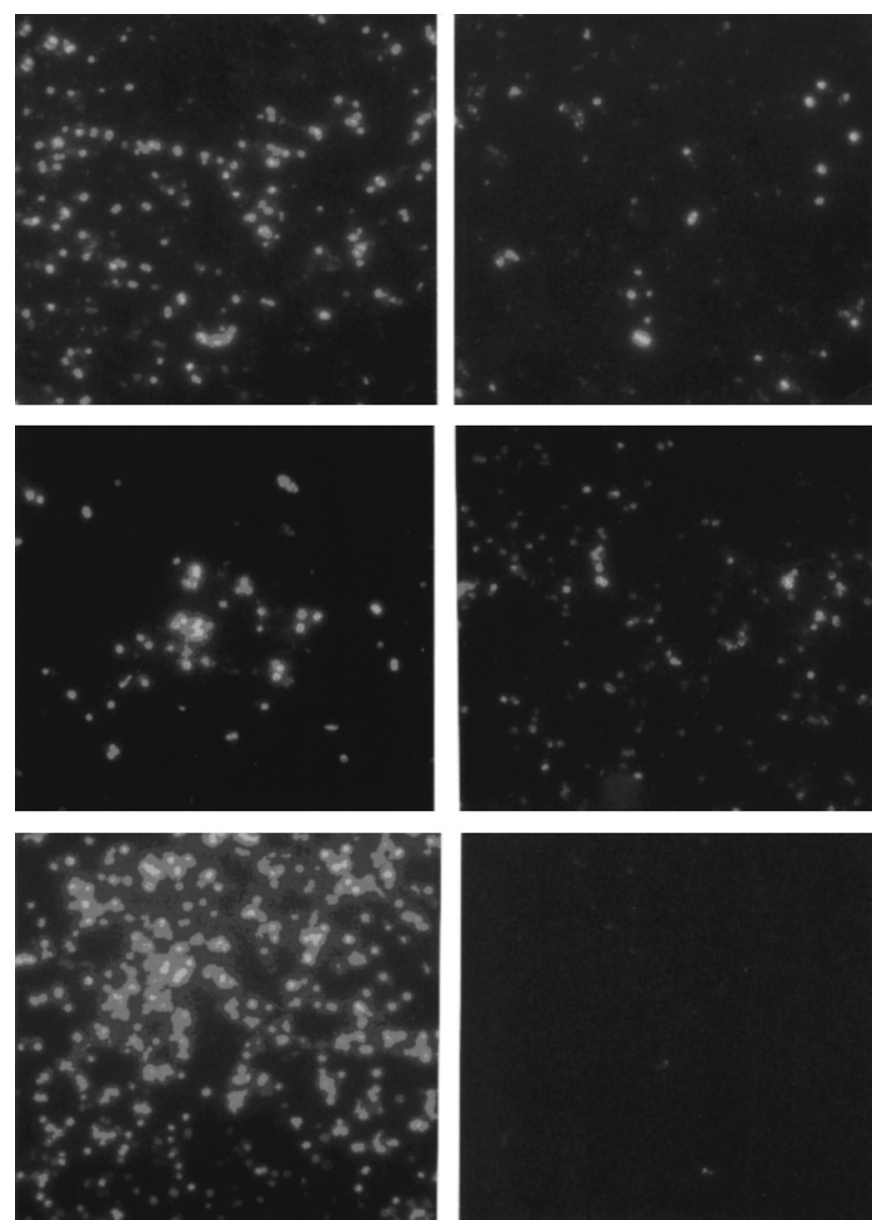

Figure 1. Immunofluorescence of $E$. coli serotypes expressing intimin subtypes. A. O127:H6 ( $\alpha$ ), B. O128:H2 ( $\beta)$, C. O157:H7 ( $\gamma)$,

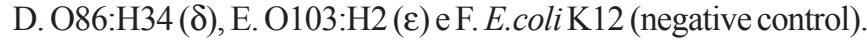
Bacterial were incubated with $4 \mu \mathrm{g} / \mathrm{mL}$ of IgG-enriched fraction of polyclonal anti-intimin antibody and FITC anti-rabbit (1:400).

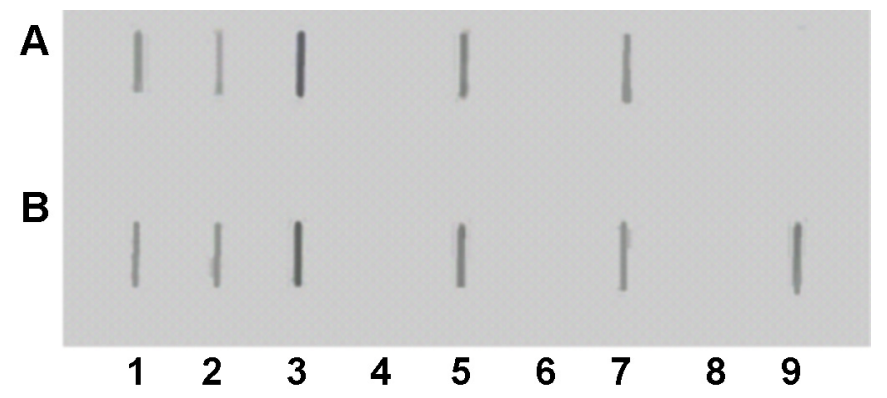

Figure 2. Immuno-dot. Different bacterial serotypes: 1. O127:H6 $(\alpha), 2 . \mathrm{O} 142: \mathrm{H} 34(\alpha), 3 . \mathrm{O} 103: \mathrm{H} 2(\varepsilon), 4 . \mathrm{O} 55: \mathrm{H} 7(\gamma), 5$. O157:H7 ( $\gamma)$, 6. E. coli K12 (negative control), 7. O128:H2 ( $\beta$ ),

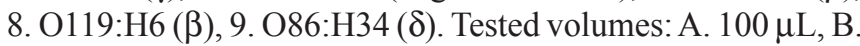
$200 \mu \mathrm{L}$. Reaction was done as described in material and methods. 
immunofluorescence, flow citometry and immunogold labeling and showed differences in bacterial strains expressing intimin subtypes. permeabilization or denaturation of protein allows this antibody to recognize intimin in bacterial strains. These results lead us to immuno-dot assay, testing the ideal pattern of capture assay, boiling bacterial growth and with the slot-blot filtration manifolds intimin could be detected by IgG-enriched fraction of anti-intimin antibody, thus our results suggest that Permeabilization or denaturation of protein from bacterial samples allow the antibody to recognize several subtypes of intimin and immuno-dot assay seems to be a possible alternative as a capture method.

\section{ACKNOWLEDGMENTS}

The authors thank Oilita Pereira Ferraz from Genetics Laboratory, Butantan Institute for technical support. This work was supported by FAPESP (grant 99/09458-0 to R.M.F.P., and fellowship to P.C.M.K.).

\section{RESUMO}

\section{Anticorpo anti-intimina: caracterização imunológica e diagnóstico de amostras de EPEC e EHEC}

EPEC e EHEC constituem um risco significativo para a saúde pública em diferentes partes do mundo. Ambas colonizam a mucosa intestinal e subvertem as funções celulares do epitélio intestinal ao produzirem uma lesão histopatológica característica, conhecida por lesão A/E (attaching-and-effacing), na qual a intimina é uma das proteínas envolvidas. A família das intiminas apresenta também uma região conservada, que compreende os aminoácidos de 388 a 667 (Int ${ }_{388-667)}$ ). O objetivo do presente trabalho foi a obtenção de um anticorpo policlonal contra a região conservada de intimina. A caracterização fenotípica das amostras de EPEC e EHEC utilizando este anticorpo permitiu observar-se a maneira variável que ele reconhece os diversos subtipos de intimina e sugere que ele seja uma ferramenta para detecção destes patógenos, sendo o ensaio de immuno-dot o método de captura de escolha.

Palavras-chave: intimina, análise fenotípica, anticorpo policlonal, EPEC,EHEC.

\section{REFERENCES}

1. Adu-Bobie, J.; Trabulsi, L.R.; Carneiro-Sampaio, M.M.S.; Dougan, G.; Frankel, G. Identification of immunodominant regions within thwe C-terminal cell binding domain of intimin $\alpha$ na intimin $\beta$ from enteropathogenic Escherichia coli. Infect. Immun., 66:5643-5649, 1998.

2. Nataro, J.P.; Kaper, J.B. Diarrheagenic Escherichia coli. Clin. Microbiol. Rev., 11:142-201, 1998.

3. Oswald, E.; Schmidt, H.; Morabito, S.; Karch, H.; Marches, O.; Capriolo, A. Typing of intimin genes in human and animal enterohemorrhagic and enteropathogenic Escherichia coli: characterization of a new intimin variant. Infect. Immun., 68:64-71, 2000.

4. Zhang, W.L.; Köhler, B.; Oswald, W.; Beutin, L.; Karch, H.; Morabito, S.; Caprioli, A.; Suerbaum, S.; Schmidt, H. Genetic diversity of intimim genes of attaching and effacing Escherichia coli strains. J. Clin. Microbiol., 40:4486-4492, 2002. 